\title{
The Effect of Ficus lyrata Warb Leaf Extract on Physicochemical and Microbiological Properties of Chicken Carcass
}

\author{
Mohamad Djali", Efri Mardawati" Herlina Marta", Dwi Wahyudha Wira*, Kiki Rizki Ramadhani", \\ Roostita L. Balia* \\ \# Department of Food Industrial Technology, Universitas Padjadjaran, Jatinangor Sumedang 40600, Indonesia \\ E-mail:agusdjali@yahoo.com,efri.mardawati@unpad.ac.id,elyne_marta@yahoo.com,kiki.rizki.ramadhani@gmail.com \\ * Department of Veterinary Medicine, Universitas Padjadjaran, Jatinangor Sumedang 40600, Indonesia \\ E-mail:dwi_drh@yahoo.com,roostita.balia@unpad.ac.id
}

\begin{abstract}
Chicken meat is one of the favorite animal protein sources consumed by Indonesian people. Its high nutrition value becomes a good place for the growth of spoilage microorganisms, such as $E$. coli, P. aerugenosa, and B. subtilis, through chemical reactions inside and outside the components. Natural preservative from plant Ficus lyrata leaf contains many antimicrobial compounds which are potential to inhibit spoilage in chicken meat. The purpose of this research was to study the effect of the addition of Ficus lyrata leaf extract in the quality degradation of broiler chicken meat during a 14-hour storage at room temperature. Observations were made on samples without and with soaking treatment in 5\%, 10\%, and $15 \%$ concentration of Ficus lyrata leaf extract. The method used was an experimental method that analyzed descriptively and was followed by regression analysis with storage time as independent variable (x) and $\mathrm{pH}$, chewiness, and total microorganisms as dependent variable (y). The results showed that soaking chicken meat on Ficus lyrata leaf extract at concentration $15 \%$ revealed the best quality during storage period. It was proved by its ability in retarding the growth of microorganisms, its slower level in forming decay, maintaining a stable pH and also texture of broiler chicken meat. At concentration $15 \%$ of Ficus lyrata leaf extract, the broiler chicken did not provide any differences in characteristics such as color, flavor, aroma and texture compared to others. The higher concentration of the extract revealed higher antimicrobial activity as a number of bioactive compounds of the extract may increase; thus, disrupting the growth of microorganisms as well as extending the shelf-life of chicken meat.
\end{abstract}

Keywords - broiler chicken meat; Ficus lyrata; phytochemical; antimicrobial; quality.

\section{INTRODUCTION}

Chicken is one of the protein sources in demand by Indonesians. High nutritional value in chicken meat causes chicken meat to become a good place for the development of spoilage microorganisms. Such a problem encourages the efforts to slow down the process of decay due to microorganisms in chicken meat by adding food additives to make the chicken last longer.

There are many preservatives that can be used to prevent food from spoilage, but natural preservatives from plants can become another alternative which is safer and less harmful to our health. Natural preservatives contain phytochemical compounds that have the effects such as antioxidant, anticancer and antimicrobial activity.

The spoilage in chicken meat or any food that is derived from animals is usually caused by spoilage microorganism such as E. coli, P. aerugenosa, and B. subtilis. E. coli has a size of 2.0-6.0 $\mu \mathrm{m}$ long. This bacterium grows at a temperature of $10-40^{\circ} \mathrm{C}$ with an optimum temperature of $37^{\circ} \mathrm{C}$, with $\mathrm{pH} 7.0-7.5$ as an optimum $\mathrm{pH}$ for its growth [1]. These bacteria belong to the anaerobic facultative bacteria, which means these bacteria can live in aerobic and anaerobic conditions and these bacteria is a gram negative bacteria [2]. B. subtilis has a rod shape, either chain or single. These bacteria are classified as gram positive bacteria and bacteria that produces endospores. The main sources of this bacteria are soil, water, air, and decomposed plant materials. The optimum temperature of $B$. subtilis to grow is $25-35^{\circ} \mathrm{C}$ and optimum $\mathrm{pH}$ between 7-8 [3]. P. aerugenosa is a gram negative, rod-shaped, non-spore-forming bacterium. $P$. aerugenosa grows well at $37^{\circ} \mathrm{C}$. These bacteria produce compounds that cause odor. Minimum $\mathrm{A}_{\mathrm{w}}$ that is needed for good growth of this bacteria is $0.96-0.98$ with optimum $\mathrm{pH}$ 6.6-7.0 [4]. P. aerugenosa is the only bacterial species that produces pyocyanin, which is a pigment that dissolves in chloroform and fluorescent and produces blue color, and also dissolves in water [5]. 
Ficus lyrata is a tropical rain forest plant that comes from the West African region. It is a species of fig tree from Moraceae family that grows well in the lowlands to the middle heights. It is a free stand-alone tree and can grow as high as 12-15 meters [6]. It has phytochemical compounds such as flavoinoid, tannin, and phenol which have antimicrobial effect [7]. The phytochemical compounds can be extracted from the plant. Previous studies conducted the extraction using maceration method with several solvents such as water, $70 \%$ alcohol, and ethyl acetate and were tested on Ficus lyrata fruit, which showed that there are tannins and phenolic components and also different antimicrobial activities in each solvent [8].

The research focused on Ficus lyrata leaf whose components have not yet been researched. The antimicrobial effect of Ficus lyrata leaf extract was analyzed by applying it to pathogen microorganism and to broiler chicken meat as solution to make it last longer and also to maintain its quality. The antimicrobial activity of Ficus lyrata leaf can be observed by testing the extract obtained from the leaf. The optimization of the extraction process is being affected by the type of solvent used, because it affects the bioactive components of Ficus lyrata leaf that can be extracted. The principle applied to the extraction process is the "like dissolves like" principle, which means the reactants will dissolve in the solvent according to their similarity of polarity properties. Nonpolar reactants will dissolve on nonpolar solvents, whereas polar reactants will dissolve on polar solvents. The solvent that is being used in the research is water. Water is an organic solvent that is easy to be found and safe to use because it does not leave any residue to the extract that is being extracted. Water is a polar solvent so it can be used to extract those antimicrobial components from Ficus lyrata leaf because the components are also polar.

The aim of this research was to study the effect of Ficus lyrata leaf extract addition in the quality degradation of broiler chicken meat during a 14-hour storage at room temperature.

\section{MATERIAL AND METHOD}

\section{A. Material}

Materials used in this study were Ficus lyrata leaves, spoilage microorganism (Eschericia coli, Pseudomonas aeruginosa, Bacillus subtili) in suspension form that is equal to Mc.Farland standard 0,5, Muller-Hinton agar (MHA), Nutrient Agar (NA), aquades, broiler chicken meat, knife, analitic scale, vacuum filter, pipet, reaction tubes, rotary evaporator, extraction jars, beaker glass, flask, stirring rod, erlenmeyer, a petri dish, bunsen, ose, sterile swabs, measuring cups, cuvette, incubators, paper disc, filter paper, tissue, uv-vis spectrophotometer, texture analyzer, and blender.

\section{B. Method}

The method used was an experimental method that analyzed descriptively and was followed by regression analysis with storage time as independent variable $(\mathrm{x})$ and $\mathrm{pH}$, chewiness, and total microorganisms as dependent variable (y). The study was conducted in four treatments, namely: control treatment, soaking treatment with a 5\%, $10 \%$, and $15 \%$ extract of Ficus lyrata leaves. The study was conducted for 14 hours with intervals of observation time in every 2 hours.

The making of Ficus lyrata leaf extract was done by maceration method using water. Dried powder Ficus lyrata leaf was extracted for 48 hours at room temperature with a ratio of Ficus lyrata leaf dried powder and solvent of 1:8 $(\mathrm{b} / \mathrm{v})$. The extract was then filtered and concentrated with rotary evaporator. The extract was then tested using antimicrobial activity test with Paper Disc Diffusion method. The antimicrobial activity was seen by the formation of a clear zone around the paper disc.

The extract was then applied to broiler chicken meat by immersion and was stored at room temperature for 14 hours, and its quality changes were being observed. Quality criteria that were observed included $\mathrm{pH}$, texture, total microorganisms, and an initial rot test on broiler chicken meat was then also performed.

1) Antimicrobial Activity Test: Pure cultures of bacteria were isolated on slant media Nutrient Agar (NA) and were incubated for $2-3$ days at $37^{\circ} \mathrm{C}$. $\mathrm{NaCl}$ fis was added about 9 $\mathrm{mL}$ in pure cultures of bacteria, then it was homogenized. Muller-Hinton agar was poured in a petri dish and was allowed to set. Bacteria were swabbed on Muller-Hinton agar's surface. Paper discs were soaked in Ficus lyrata leaf extract for 7 minutes aseptically. Soaked paper discs were lifted using sterile tweezers and were placed on MullerHinton agar's surface. Medias are incubated for 2-3 days at $37^{\circ} \mathrm{C}$. Calculation of antimicrobial activity was characterized by the formation of a clear zone on Muller-Hinton agar around the paper disk.

2) Total Plate Count: As much as $5 \mathrm{~g}$ of chicken meat was weighed from the broiler's carcasses. Afterwards, $45 \mathrm{ml}$ of $0.1 \% \mathrm{NaCl}$ fis sterile was added into the sample, and was then shaken with a vortex for 1 to 2 minutes. This is a solution to a $10^{-1}$ dilution. After that, $1 \mathrm{ml}$ of $10^{-1}$ dilution suspension was moved with a sterile pipette to a solution of $9 \mathrm{ml}$ of $\mathrm{NaCl}$ fis to get a $10^{-2}$ dilution. The dilution of $10^{-3}$, $10^{-4}, 10^{-5}$, and so on was created in the same manner. And then $1 \mathrm{ml}$ suspension of each dilution was added into a petri dish in duplo. Next, $15 \mathrm{ml}$ to $20 \mathrm{ml}$ of PCA that has been cooled to the temperature of $45^{\circ} \mathrm{C} \pm 1{ }^{\circ} \mathrm{C}$ was added in each petri dish already containing a suspension. Later, the dilution was mixed and was let to stand until it became solid. It was then incubated at temperatures of $34^{\circ} \mathrm{C}$ up to $36^{\circ} \mathrm{C}$ for 24 hours up to 48 hours.

3) Lead Acetate Test: Chicken meat was put in a petri dish and then a filter paper was laid on top of the meat. Then, $10 \%$ lead acetate was dropped on filter paper which covered the meat. After 2-3 minutes, the changes in filter paper were observed. If brown or black dots were formed, it means the meat has undergone a process of early decay.

4) $p H$ Test: $\mathrm{pH}$ meter was calibrated with buffer solution $\mathrm{pH} 4$ and 7, and then the electrode was rinsed with distilled water and it was later dried. Samples of 5-gram meat were minced and mixed with $25 \mathrm{ml}$ of distilled water, and were then shaken until it became homogeneous. The electrode 
was later dipped into the sample and the $\mathrm{pH}$ value will be read on the screen of the $\mathrm{pH}$ meter.

5) Chewiness: Meat samples were measured using TA.XT2 Texture Analyzer. The tool was prepared at a convenient place and was connected to a laptop. The laptop was afterwards switched on, and Exponent Lite Express program was selected. In the program, Sample Project was selected and Parameter Analysis (TA.PRJ) was clicked twice. Samples that had been prepared earlier were placed on the tool and the test selected from the menu box was run, with Texture Analyzer started working. Data charts were shown after the measurement had been done.

\section{RESULT AND DISCUSSION}

\section{A. Antimicrobial Activity}

The determination of antimicrobial activity is performed in-vitro using agar diffusion. The antimicrobial activity is being seen based on the forming of clear zone around the tested sample. The clear zone shows the resistance of microbial growth to the layer of solid agar in the petri dish. Results of testing the antimicrobial activity of the leaf extract of Ficus lyrata on some spoilage bacteria that are Pseuodomonas aeruginosa, Escherichia coli and Bacillus substilis presented in Fig. 1 below.

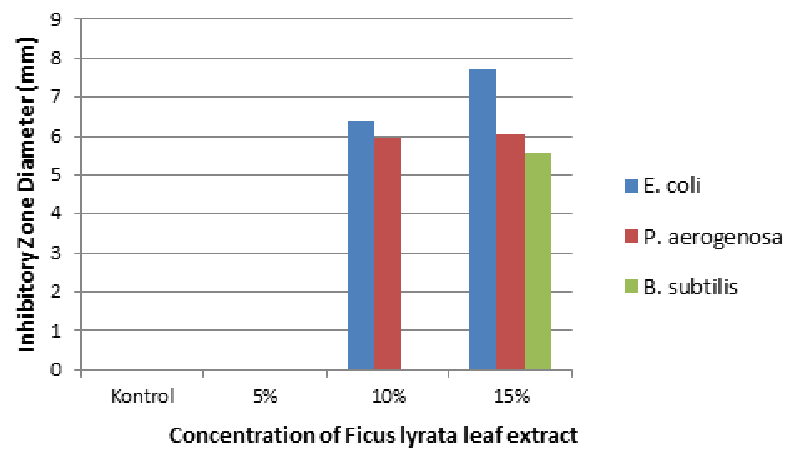

Fig.1 The inhibition diameter (Clear Zone) of Ficus lyrata Leaf Extract

The results showed that the higher concentration of Ficus lyrata leaf extract used, the larger clear zone it forms. The clear zone shows the ability of antimicrobial compound in inhibiting the growth of microorganism. The large area of clear zone indicates the stronger antimicrobial activity in against the existence of microorganism, vice versa [9]. This large clear zone was formed because the higher amount of pure antimicrobial compounds extract may be presented in higher concentration of Ficus lyrate. Broiler chicken meat with soaking treatment in 5\% Ficus lyrata leaf extract did not show clear zone. This might be explained by the number of antimicrobial compounds present in 5\% Ficus lyrata leaf extract which are not equivalent to the minimum concentration in inhibiting the growth of all three bacteria tested. Therefore, its presence did not give any effect to the growth of bacteria. One of the factors which affect the activity of antimicrobials is its concentration, thus, the higher the concentration be, the more effective its antimicrobial effect may be [10].

From the graph, it can be seen that the activity of Ficus lyrata leaf extract shows the best result in prohibiting the growth of bacteria Eschericia coli. It is indicated by the larger clear zone which is shaped compared to other types of bacteria. The difference of characteristics of each bacterium may become the factors that affected the activity of antimicrobials [10].

The antimicrobial activity of Ficus lyrata leaf extract did not work in prohibiting the growth of Bacillus subtilis as good as in the other spoilage bacteria as the clear zone of it is only showed up in $15 \%$ concentration soaking treatment. This phenomenon may be caused by the Bacillus subtilis classified as a gram positive bacteria. It has different characteristic with gram negative bacteria.

There are some active compounds contained in Ficus lyrata leaf, such as phenol, flavonoid, triterpenoid, and tannin. Phenol compounds can hinder the synthesis of protein and also disrupt enzymatic process that interfere with cell metabolism by dissolving fat in cell walls. The cell wall of gram-negative bacteria has an outer membrane besides peptidoglycan that is formed by lipopolysaccharides, lipoproteins, and periplasm that are bound to peptidoglycan [11]. Those abilities of phenol compounds cause Ficus lyrata's leaf extract works well to inhibit the growth of gram-negative bacteria which also spoilage microorganisms [10].

\section{B. Pb Acetate Test}

This test use $\mathrm{Pb}$ acetate method which is a qualitative method to detect a forming decay quickly and directly. This test uses $\mathrm{Pb}$ acetate to find out the presence of $\mathrm{H}_{2} \mathrm{~S}$ gas as an indicator of the presence of spoilage bacteria. $\mathrm{H}_{2} \mathrm{~S}$ is one of the metabolites produced by the process of protein reshuffle by spoilage microorganisms which is then released by the spoilage microorganisms found in meat. The table below shows the result of the test.

TABLE I

Result of PB ACETATE Test

\begin{tabular}{|c|c|c|c|c|c|c|c|c|}
\hline \multirow{2}{*}{ Treatment } & \multicolumn{7}{|c|}{ Storage Time (Hours) } \\
\cline { 2 - 9 } & 0 & 2 & 4 & 6 & 8 & 10 & 12 & 14 \\
\hline A (control) & - & - & - & - & + & + & + & + \\
\hline B (5\%) & - & - & - & - & - & - & - & + \\
\hline C (10\%) & - & - & - & - & - & - & - & + \\
\hline D (15\%) & - & - & - & - & - & - & - & - \\
\hline
\end{tabular}

A positive sign (+) indicates that there is a change in the color of the filter paper to brown. This means that the tested sample has produced $\mathrm{H}_{2} \mathrm{~S}$. The existence of $\mathrm{H}_{2} \mathrm{~S}$ indicates that the spoilage microorganisms has grown in the sample. $\mathrm{H}_{2} \mathrm{~S}$ is released by the spoilage microorganisms binds to $\mathrm{Pb}$ acetate and formed $\mathrm{Pb}$ sulfite $\left(\mathrm{PbSO}_{3}\right)$ and produced a brown color on the filter paper. One of the spoilage microorganisms that produces $\mathrm{H}_{2} \mathrm{~S}$ is Pseudomonas. Pseudomonas also produce enzymes that are able to break down fats and proteins, so it can cause the smell of rotten and mucus in the food [12].

Based on the table, the decay of chicken meat on control treatment started showing the rottenness at the $8^{\text {th }}$ hour. The chicken meat with the addition of 5\% and 10\% Ficus lyrata leaf extract experienced decay at the $14^{\text {th }}$ hour strorage while chicken meat with the addition of $15 \%$ Ficus lyrata leaf extract did not show results of decay. This suggests that soaking a broiler chicken meat in Ficus lyrata leaf extract can delay the decay process of broiler chicken meat. 


\section{C. $p H$}

The result of $\mathrm{pH}$ observation on broiler chicken meat during 14 hours storage can be seen in Fig. 2. Based on the regression equation shown in the Fig. 2, the increasing rate of broiler chicken meat's $\mathrm{pH}$ is higher in broiler chicken meat without the addition of Ficus lyrata leaf extract and the increasing rate is getting lower as the increasing amount of extract's concentrations. The increase of $\mathrm{pH}$ can be affected by the growth of microorganism, especially the spoilage bacteria that produce metabolites in the form of ammonia which is alkaline [13].

In addition, the $\mathrm{pH}$ conditions for each treatment in the beginning of experiment were different because the initial $\mathrm{pH}$ was measured after the broiler chicken was soaked according to research methodology. This difference may be explained by the condition and broiler chicken management after slaughtering.


Fig. 2 Graphic of $\mathrm{pH}$ Changes on Storage Time

As mentioned earlier, the growth of microorganisms strongly relates with the number of antimicrobial components in Ficus lyrata. The higher the concentration of Ficus lyrata leaf extract was added into the meat, the more antimicrobial compounds were presented. Therefore, higher concentration of extract can slow down the rising of $\mathrm{pH}$ condition. Some factors, such as the amount of lactic acid produced by glycogen during aerobic glycolysis and the total number of microorganisms in the beginning are also considered to affect $\mathrm{pH}$ number [14].

Unstable $\mathrm{pH}$ was also found during 14 hours storage. This might be explained by rigor mortis mechanism. Rigor mortis process occurs after slaughtering for 24-48 hours. This process also had complex biochemical reaction in which creatine phosphate and adenosine triphosphate (ATP) were vanished from muscles. The speed of rigor mortis development is influenced by several factors. They are glycogen level at the time of death and temperature of carcass [9].

The value of $R^{2}$ is higher than 0.75 . Also, the value of $r$ that is positive and close to 1 shows that there is a strong relation between the two variables.

\section{Total Microbial}

The increasing number of microorganisms causes decay in meat. Meat possesses plenteous nutrients that can be used as a place for microorganism to grow up. Bacteria can reproduce continuously when being placed in an ideal condition or with enough nutrients. The result of total microorganism in broiler chicken meat for 14 hours storage is illustrated in Fig. 3.

Based on the figure, it can be seen that the greatest increase in total microbial occurs in broiler chicken meat without soaking treatment. Thus, it goes off and runs into decay quickly. Besides, the addition of Ficus lyrata leaf extract can control the growth of microorganisms in chicken broiler quite satisfactorily.

The value of $R^{2}$ is higher than 0.75 . Also, the value of $r$ that is positive and close to 1 shows that there is a strong relation between the two variables.

Based on SNI 3924:2009, the maximum value of total microbial is $1,0 \times 10^{6} \mathrm{cfu} / \mathrm{g}$. The soaking treatment in Ficus lyrata leaf extract does not actually make total microbial decrease, but it can inhibit the growth of microorganism so that the result will not be as high as the one without any soaking treatment.

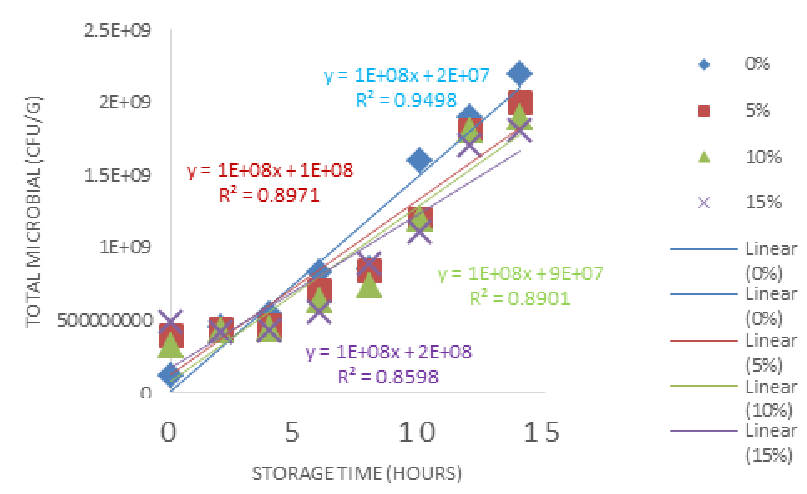

Fig. 3 Graphic of Total Microbial on Storage Time

\section{E. Chewiness}

The result of chewiness value of broiler chicken meat during 14 hours storage can be seen in Fig. 4 below. Based on Fig. 4, it can be seen that the greatest decrease occurs in broiler chicken meat without soaking treatment so that it goes off and runs into decay quicker. The decrease of chewiness value means that the meat becomes tenderer than before. The change of texture in chicken meat is caused by its components such as constituent of connective tissue and filament yarns in the broiler chicken meat which are partially damaged as a result of changes in biochemical and antimicrobial activity. This means that there is no more strength to sustain the structure of the broiler chicken meat which resulted in texture change of the meat [12]. Besides, the characteristics of food during storage in room temperature can also affect the chewiness because of denaturation of protein. This degradation will reduce the water-holding capacity of meat. Thus, it becomes tender and moist [15].

The loss of chewiness is followed by appearance of water around the chicken meat. The water around the chicken meat is also being caused by the damaged of constituent of connective tissue and filament yarns is causing the water content decreased from the meat. The degradation of protein reduces the water holding capacity of the chicken meat and that makes the chewiness of chicken meat decrease [15]. The situation where water is surrounding the meat also leads to faster decaying process of the chicken meat because the 
water around that leaks out of the chicken is causing the moisture of environment around it higher and it is good for the growth of spoilage microorganism.



Fig. 4 Graphic of Chewiness Value Changes on Storage Time

The value of $\mathrm{R}^{2}$ is higher than 0.75 . Also, the value of $r$ that is positive and close to 1 shows that there is a strong relation between the two variables.

\section{F. Organoleptic Test}

Organoleptic test was done using broiler chicken meat with the best treatment, which is with an addition of $15 \%$ Ficus lyrata leaf extract. The test used in this study was Triangle test. Three pieces of meat sample were served at once and were observed in terms of color, flavor, smell, and texture.

Most of panelists judged that the code 452 meat has a different color, aroma, flavor, and texture. A total of 7 out of 16 panelists stated that sample 452 has a different color than the other two samples. A total of 8 out of 16 panelists stated that sample 452 has a different flavor than the other two samples. A total of 8 out of 16 panelists it stated that sample 452 have a different texture than the other two samples. The aroma on samples 452 and 654 were equally expressed differently by six panelists, whereas only 4 out of 16 people said that sample 187 was different from the others.

Based on the table of Triangle test [16], the smallest number to declare a significant difference in this test with a level of 5\% within 16 panelists were 9 people. It is proved that all parameters that are being tested, in terms of color, taste, aroma, and texture, none of them has a significant difference to each other because the largest number of panelists who expressed difference is still less than the smallest amount to state depending on the triangle test for 16 panelists. The test leads us to the conclusion that with addition of Ficus lyrata extract as a natural preservative does not give significant effect to the appearance and presentation of chicken meat despite its ability to prevent any quality degradation of the chicken meat

\section{CONCLUSIONS}

Soaking treatment of chicken carcass in $15 \%$ of Ficus lyrata leaf extract can inhibit quality degradation, by not showing the different characteristics in terms of color, flavor, aroma, and texture when being compared with the chicken carcass without soaking treatment. The antimicrobial components in the extract works really well to inhibit the bacteria that is classified in gram negative bacteria rather than the gram-positive bacteria because of the difference in the characteristics of each bacteria, specifically in the cell wall components.

\section{ACKNOWLEDGMENT}

This research was funded by the Ministry of Research, Technology, and Higher Education of the Republic of Indoensia under the scheme of Science and Technology Application Research 2015.

\section{REFERENCES}

[1] M. Mik`s-Krajnik, Y.Yoon, D. O. Ukuku, and H. Yuk, "Identification and quantification of volatile chemical spoilage indexes associated with bacterial growth dynamics in aerobically stored chicken," Journal of Food Science, vol. 81, no. 8, pp. M1-M9, 2016.

[2] G. Pathiraja, P. Edogawatta, A. Goonetilleke dan V. S. J. Te'o, "Solubilization and degradation of polychlorinated biphenyls (PCBs) by naturally occurring facultative anaerobic bacteria," Science of The Total Environment, vol. 651, no. 2, pp. 2197-2207, 2019.

[3] B. Hadimani dan S. Kulkarni, "Ideal Growth Conditions for Mass Production of Biocontrolagent Bacillus subtilis (Ehrenberg) Cohn," Plant Archives, vol. 17, no. 1, pp. 535 - 538, 2017.

[4] A. Gotor-Vila, N. Teixido, M. Sisquella, R. Torres, J. Usall, "Biological characterization of the biocontrol agent Bacillus amyloliquefaciens CPA-8: the effect of temperature, $\mathrm{pH}$ and water activity on growth, susceptibility to antibiotics and detection of enterotoxic genes," Current Microbiology, vol. 74, no. 9, pp. 10891099, 2017.

[5] K. Todar, "Pseudomonas aeruginosa," 2008. [Online]. Available: http://textbookofbacteriology.net/pseudomonas.html. [Diakses 2504 2019].

[6] H. Nadel, J. H. Frank and R.J. Knight, "Escape and accomplices: the neutralization of exotic Ficus and their associated faunas in Florida," Journal of Enthomologist, vol. 75, no. 1, pp. 29 - 38, 2003.

[7] M. Jagathambal, K. Madhavan, Parvathi, and G. Kaarunakaran, "Phytochemical screening antimicrobial activity of seven solvent extracts of dried fruit of Ficus cairca against five human pathogenic bacteria," Journal of Pharmacy Research, vol. 4, no. 12, pp. 4498 4500, 2011.

[8] E.S. Abdel-Hameed, "Total phenolic contents and free radical scavenging activity of certain Egyptian Ficus species leaf samples," Food Chemistry, pp. 1271-1277, 2009.

[9] S. Manandhar, S. Luitel dan R. K. Dahal, "In Vitro Antimicrobial Activity of Some Medicinal Plants against Human Pathogenic Bacteria," Journal of Tropical Medicine, vol. 2019, pp. 1-5, 2019.

[10] J. Li, S. Xie, S. Ahmed, F. Wang, Y. Gu, C. Zhang, X. Chai, Y. Wu, J. Cai and G. Cheng, "Antimicrobial activity and resistance: influencing factors," Frontiers in Pharmacology, vol. 8, no. 364, pp. 1-11, 2017.

[11] S. P. Denyer, N. A. Hodges, S. P. Gorman, and B. F. Gilmore, Hugo and russell's pharmaceutical microbiology, Massachusetts: Blackwell Publishing Company, 2004.

[12] M. Mesri, M. J. Behzadnia dan G. Dorooshi, "Accelerated rigor mortis: A case letter," Journal Research in Medical Science, vol. 22, no. 126, 2017.

[13] P.D. Cotter and C. Hill, "Surviving the Acid Test: Responses of Gram-Positive Bacteria to Low pH," Microbiology and Molecular Biology Review, vol. 67, no. 3, pp. 429 - 453, 2003.

[14] J. Wan, Z. Qin, P. Wang, and X. Liu, "Muscle fatigue: general understanding and treatment," Experimental \& Molecular Medicine, vol. 49, no. 10, pp. 1-11, 2017.

[15] W. Guo dan M. L. Greaser, "Muscle Structure, Proteins, and Meat Quality," dalam New Aspects of Meat Quality: From Genes to Ethics, Cambridge, Woodhead Publishing, 2017, pp. 13-31.

[16] F. Ayustaningwarno, Teknologi Pangan; Teori Praktis dan Aplikasi, Yogyakarta: Graha Ilmu, 2014. 